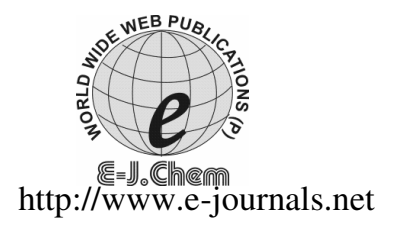

ISSN: 0973-4945; CODEN ECJHAO

E-Journal of Chemistry

2011, 8(3), 1164-1173

\title{
Hydrochemical Formation Mechanisms and Quality Assessment of Groundwater with Improved TOPSIS Method in Pengyang County Northwest China
}

\author{
LI PEIYUE, QIAN HUI and WU JIANHUA \\ School of Environmental Science and Engineering \\ Chang'an University, No.126 Yanta Road, Xi'an, 710054, China \\ lipy2@163.com
}

Received 12 October 2010; Accepted 16 December 2010

\begin{abstract}
Inverse geochemical modeling was used in this paper to quantitatively study the formation mechanisms of groundwater in Pengyang County, China. An improved TOPSIS method based on entropy weight was used to perform groundwater quality assessment in this area. The assessment results show that the groundwater in the study area is fit for human consumption and the high concentrations of some elements can be attributed to the strong water-rock interactions. The inverse geochemical modeling reveals that the dominant reactions in different parts of the study area are different. In the south part of the study area, the precipitation of sodium montmorillonite, calcite and the dissolution of gypsum, fluorite, halite, albite and dolomite as well as $\mathrm{CO}_{2}$ dissolution and cation exchange are the major water-rock interactions, while in the north part, the leading reactions are the precipitation of gypsum, dolomite, sodium montmorillonite, fluorite, the dissolution of calcite and albite and the $\mathrm{CO}_{2}$ emission and cation exchange are also important. All these reactions are influenced by the initial aquatic environment and hydrodynamic conditions of the flow path.
\end{abstract}

Keywords: Hydrochemical characteristics, Formation mechanism, Groundwater quality assessment, TOPSIS model, Pengyang County

\section{Introduction}

Groundwater is regarded as one of the most valuable and essential natural resources, yet fresh groundwater systems have been directly and continuously threatened by human activities recent years. Groundwater is used to irrigate more than $40 \%$ of China's farmland, and for about $70 \%$ of the drinking water in the dry northern and northwestern regions ${ }^{1}$. The availability of fresh groundwater is an urgent and essential issue in China. The study on the 
hydrochemical formation mechanism and quality of groundwater has become a hot research topic worldwide and many advanced technologies and tools have come out. Inverse geochemical modeling, a theory for geochemical and evolution of groundwater research, has been developed and introduced into hydrochemical simulation. Many scholars around the world have performed a series of hydrogeochemical simulation regarding to the hydrochemical formation mechanisms. Wang et al. ${ }^{2}$ used the hydrogeochemistry and isotope hydrogeology to investigate the karst groundwater systems at Pingdingshan coalfield and discussed the feature of karst development using the speciation modeling and mass balance approach. Gillon et al. ${ }^{3}$ used a solid solution approach for the modeling of calcite dissolution in the Chalk aquifer of Champagne (France). Li et al. ${ }^{4}$ preformed geochemical modeling of groundwater in southern plain area of Pengyang County. They performedhydrogeochemical modeling using PHREEQC software comprehensively and precisely.

Groundwater is essential natural resources mainly for drinking in Pengyang County. The water quality here is determined by the hydrogeological conditions and hydrodynamic conditions and hence the study on the hydrochemical formation mechanism is important to groundwater rational development and groundwater protection. Till now, little work has been done in this field and it is required and needed to do a comprehensive study on the hydrochemical formation mechanism and the status of groundwater quality. This paper mainly deals with this problem.

\section{Experimental}

Pengyang County is situated in the south of Ningxia Hui Autonomous Region, east of the Liupan Mountains, between longitude $106^{\circ} 32^{\prime} \mathrm{E}$ and $106^{\circ} 58^{\prime} \mathrm{E}$, and latitude $35^{\circ} 41^{\prime} \mathrm{N}$ and $36^{\circ} 17^{\prime} \mathrm{N}$. The area is $62 \mathrm{~km}$ long from south to north and $58 \mathrm{~km}$ wide from east to west and covers $3241.1 \mathrm{~km}^{2}$. Multi-year mean rainfall is about $500 \mathrm{~mm}$ in the area. Annual precipitation is mainly concentrated in July, August and September and the total precipitation of those three months accounts for nearly $60 \%$ of the total precipitation over the whole year. Groundwater is a little alkaline with $\mathrm{pH}$ value varying between 7.85 and 8.36 . Hydrochemical types are mostly the $\mathrm{HCO}_{3} \cdot \mathrm{SO}_{4}$ $\mathrm{Na} \cdot \mathrm{Mg} \cdot \mathrm{Ca}$ type and the $\mathrm{HCO}_{3} \cdot \mathrm{SO}_{4}-\mathrm{Na} \cdot \mathrm{Mg}$ type ${ }^{4}$. The Quaternary sand and gravel aquifer is the main water-bearing formation for the water supply in the area and is also the layer of interest in this study.

In this study, a total of 74 groundwater samples were collected, of which 6 samples were used for inverse geochemical modeling. The data used for geochemical modeling are listed in Table 1 . The 74 representative samples were collected from different shallow monitoring wells (depths were usually 10-20 m) in August 2007. Sampling locations are shown in Figure 1. Samples were collected in pre-cleaned plastic polyethylene bottles for physicochemical analysis. Prior to sampling, all the sampling containers were washed and rinsed thoroughly with the groundwater to be taken for analysis. The $\mathrm{pH}$ values of samples were measured on site using a portable $\mathrm{pH}$ meter, the other indices such as carbonate, bicarbonate, chloride, sulphate, phosphate, calcium, magnesium, sodium, potassium, $\mathrm{pH}$, chemical oxygen demand (COD), total dissolved solids (TDS), total hardness (TH), nitrate, ammonia nitrogen, fluoride, total iron (Tfe), total alkalinity, total acidity, chroma, arsenic, iodine, aluminum, nitrite, metasillicio acid and free carbon dioxide were analyzed by the laboratory of the Ningxia geological and environmental monitoring station. 
Table 1. Water quality analysis results along simulated paths

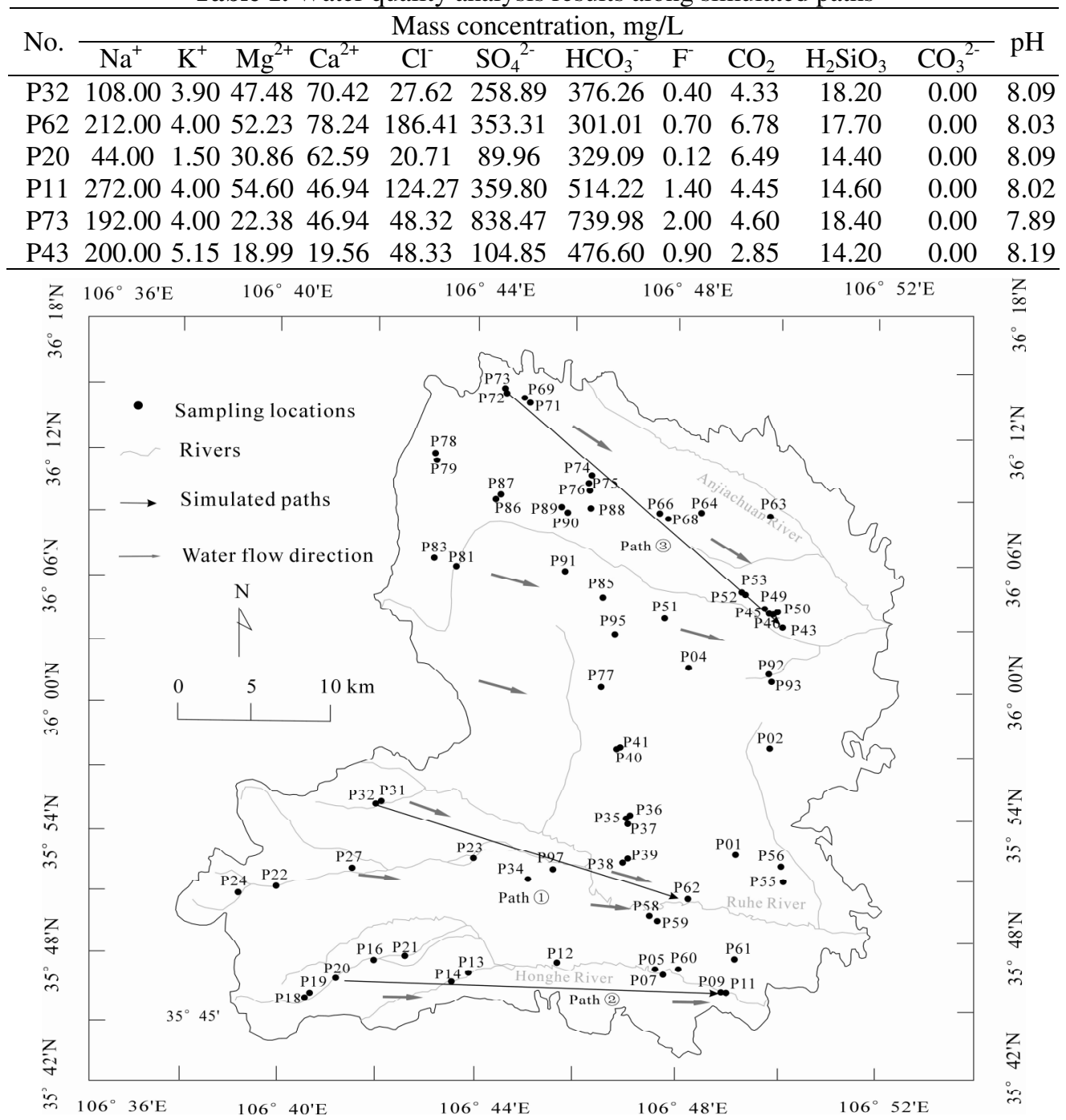

Figure 1. Sampling locations and simulated paths in study area

\section{Inverse geochemical modeling}

Geochemical modeling was developed in the 1960s on the basis of equilibrium thermodynamics. It primarily uses chemical and mathematical methods to express geochemical processes in natural water system and water-rock system, and to simulate and predict the geochemical reactions in multivariable and multi-component open system for solving a series of important theoretical and practical issues in geological and environmental sciences. Hydrogeochemical modeling of groundwater flow can explain the processes of groundwater and rock interactions and can also quantitatively describe the migration and transformation of various elements in groundwater to predict the evolution trend of groundwater chemical characteristics. It is an effective way to study the groundwater chemistry characteristics. 
Inverse geochemical modeling mostly performed in PHREEQC is based on a geochemical mole-balance model. It calculates the phase mole transfers (the moles of minerals and gases that must enter or leave a solution) to account for the differences in an initial and a final water composition along the flow path in a groundwater system ${ }^{5}$. The key concepts and terminology used in constructing net geochemical mass balance reactions are constraints, phases and models ${ }^{6}$. The basic equation expressing the phase mole transfers is as follows:

$$
\sum_{j=1}^{n} a_{i j} x_{j}=b_{i}
$$

Where $a_{i j}$ is the stoichiometric number of the $i^{\text {th }}$ element in relation to the $j^{\text {th }}$ mineral, a dimensionless value equal to the molar number of $i^{\text {th }}$ element generated by the complete dissolution of $1 \mathrm{~mol}$ of $j^{\text {th }}$ mineral; $x_{j}$ is the molar number that the $j^{\text {th }}$ mineral precipitates or dissolves (positive for dissolution and negative for precipitation) and $b_{i}$ is the increment of the $i^{\text {th }}$ element in the end water quality. The equations composed of the model are listed in Table 2.

Table 2. Equations of mineral (gas) dissolution

\begin{tabular}{|c|c|}
\hline Mineral & Equation of mineral (gas) dissolution \\
\hline Gypsum & $\mathrm{CaSO}_{4} \cdot 2 \mathrm{H}_{2} \mathrm{O}=\mathrm{Ca}^{2+}+\mathrm{SO}_{4}{ }^{2-}+2 \mathrm{H}_{2} \mathrm{O}$ \\
\hline Sodium montmorillonite & $\begin{array}{l}3 \mathrm{Na}_{0.33} \mathrm{Al}_{2.33} \mathrm{Si}_{3.67} \mathrm{O}_{10}(\mathrm{OH})_{2}+30 \mathrm{H}_{2} \mathrm{O}+6 \mathrm{OH}^{-}= \\
\mathrm{Na}^{+}+7 \mathrm{Al}(\mathrm{OH})_{4}^{-}+11 \mathrm{H}_{4} \mathrm{SiO}_{4}\end{array}$ \\
\hline Fluorite & $\mathrm{CaF}_{2}=\mathrm{Ca}^{2+}+2 \mathrm{~F}^{-}$ \\
\hline Calcite & $\mathrm{CaCO}_{3}=\mathrm{Ca}^{2+}+\mathrm{CO}_{3}^{2-}$ \\
\hline Halite & $\mathrm{NaCl}=\mathrm{Na}^{+}+\mathrm{Cl}^{-}$ \\
\hline Dolomite & $\mathrm{CaMg}\left(\mathrm{CO}_{3}\right)_{2}=\mathrm{Ca}^{2+}+\mathrm{Mg}^{2+}+2 \mathrm{CO}_{3}{ }^{2-}$ \\
\hline $\mathrm{CO}_{2}$ & $\mathrm{CO}_{2}+\mathrm{H}_{2} \mathrm{O}=\mathrm{H}_{2} \mathrm{CO}_{3}$ \\
\hline Albite & $\mathrm{NaAlSi}_{3} \mathrm{O}_{8}+8 \mathrm{H}_{2} \mathrm{O}=\mathrm{Na}^{+}+\mathrm{Al}(\mathrm{OH})_{4}^{-}+3 \mathrm{H}_{4} \mathrm{SiO}_{4}$ \\
\hline K-feldspar & $\mathrm{KAlSi}_{3} \mathrm{O}_{8}+8 \mathrm{H}_{2} \mathrm{O}=\mathrm{K}^{+}+\mathrm{Al}(\mathrm{OH})_{4}^{-}+3 \mathrm{H}_{4} \mathrm{SiO}_{4}$ \\
\hline Cation exchange & $2 \mathrm{NaX}+\mathrm{Ca}^{2+} \leftrightarrow 2 \mathrm{Na}^{+}+\mathrm{CaX}_{2}$ \\
\hline
\end{tabular}

\section{Entropy weighted TOPSIS method}

TOPSIS (Technique for Order Preference by Similarity to Ideal Solution) method is one of the most classical methods for solving multi-criteria decision-making problems, which was first developed by Hwang and Yoon ${ }^{7}$. The specific steps of TOPSIS method used in water quality assessment can be expressed as follows ${ }^{8-11}$.

Step 1: Construction of the initial decision matrix

Assume there are $m$ samples to be evaluated against $n$ indices. The problem can be concisely expressed in matrix format as Equation. (1).

$$
\mathbf{C}=\left[\begin{array}{cccc}
c_{11} & c_{12} & \cdots & c_{1 n} \\
c_{21} & c_{22} & \cdots & c_{2 n} \\
\vdots & \vdots & \ddots & \vdots \\
c_{m 1} & c_{m 2} & \cdots & c_{m n}
\end{array}\right]
$$

Where, $\mathrm{C}$ is the initial decision matrix, $c_{i j}$ is the observed values of samples, $i=1,2 \ldots m$ and $n=1,2 \ldots n$.

Step 2: Normalization of the initial decision matrix 
Because in the initial decision matrix, complex relations exist, the initial matrix must be standardized to eliminate anomalies with different measurement units and scales. The standardized matrix is expressed as follows.

$$
\mathbf{R}=\left[\begin{array}{cccc}
r_{11} & r_{12} & \cdots & r_{1 n} \\
r_{21} & r_{22} & \cdots & r_{2 n} \\
\vdots & \vdots & \ddots & \vdots \\
r_{m 1} & r_{m 2} & \cdots & r_{m n}
\end{array}\right]
$$

Where, $\mathbf{R}$ is the standardized decision matrix, $r_{i j}=\left\{\begin{array}{l}c_{i j} /\left[\sum_{i=1}^{m} c_{i j}^{2}\right]^{\frac{1}{2}} \text { efficiency type } \\ -c_{i j} /\left[\sum_{i=1}^{m} c_{i j}^{2}\right]^{\frac{1}{2}} \quad \text { cost type }\end{array}\right.$

Step 3: Determination of the weight for each index

Because the indices have different significance for the quality assessment, the weight of each index should be determined with information entropy theory ${ }^{12-16}$. After the weights are determined, a weighted standardized matrix $\mathrm{F}=\left(f_{i j}\right)_{m \times n}$ can be obtained according to the following formula.

$$
f_{i j}=r_{i j} \times \omega_{j}
$$

Where, $f_{i j}$ is the weighted standardized value, $r_{i j}$ is the standardized value, $\omega_{j}$ is the entropy weight.

Step 4: Determination of the positive and negative ideal reference points

The positive and negative ideal reference points can be outlined as follows:

$$
\text { Let }\left\{\begin{array}{l}
{f_{j}}^{+}=\max \left\{f_{1 j}, f_{2 j} \ldots f_{m j}\right\} \\
f_{j}{ }^{-}=\min \left\{f_{1 j}, f_{2 j} \ldots f_{m j}\right\}
\end{array} \quad(j=1,2, \ldots n)\right.
$$

The positive ideal reference point is:

$$
G=\left\{f_{1}^{+}, f_{2}^{+} \ldots f_{n}^{+}\right\}
$$

And the negative ideal reference point is

$$
B=\left\{f_{1}{ }^{-}, f_{2}{ }^{-} \ldots f_{n}{ }^{-}\right\}
$$

Step 5: Calculation of the distances to the positive and negative ideal reference points

The distances to the positive and negative ideal reference points are calculated using the following formulas:

$$
\left\{\begin{array}{l}
d^{+}=\sqrt{\sum_{j=1}^{n}\left[f_{i j}-\left(f_{i j}\right)_{G}\right]^{2}} \\
d^{-}=\sqrt{\sum_{j=1}^{n}\left[f_{i j}-\left(f_{i j}\right)_{B}\right]^{2}}
\end{array}\right.
$$

Where, $\left(f_{i j}\right)_{G}$ and $\left(f_{i j}\right)_{B}$ are the values in the positive and negative ideal reference points respectively., $\mathrm{d}^{+}$and $\mathrm{d}^{-}$are the distances to the positive and negative ideal reference points, respectively. 
Step 6: Calculation of the closeness coefficient of each sample and water quality assessment The closeness coefficient $(C C)$ can be calculated as follows:

$$
C C=\frac{d^{-}}{d^{+}+d^{-}}
$$

After the closeness coefficients have been calculated, the groundwater quality can be determined according the order of the closeness coefficients. The bigger the value of $C C$, the better the groundwater quality is.

\section{Results and Discussion}

\section{Groundwater quality assessment}

The major irons in groundwater determine the water chemical types. It can be seen from the piper diagram of groundwater (Figure 2) that the most predominant anions in groundwater are $\mathrm{Na}^{+}, \mathrm{HCO}_{3}{ }^{-}$and $\mathrm{SO}_{4}{ }^{2-}$ which indicates that the water chemical types of groundwater in the study area are mainly $\mathrm{Na}$ type with cations and $\mathrm{HCO}_{3}{ }^{-}$and $\mathrm{SO}_{4}{ }^{2-}$ type with anions.

The high concentration of $\mathrm{SO}_{4}{ }^{2-}$ may be attributed to little rain, high temperature and strong evaporation as well as aquifer medium abundant in sulphate in the area. Enrichment induced by evaporation and strong water-rock interaction both affect the concentration of $\mathrm{SO}_{4}{ }^{2-}$. The high concentrations of $\mathrm{Na}^{+}$and $\mathrm{HCO}_{3}{ }^{-}$can be mostly attributed to strong waterrock interaction. When the water flows across the aquifer media, the $\mathrm{Na}^{+}$abundant rocks and $\mathrm{HCO}_{3}{ }^{-}$abundant rocks dissolve into the water and hence increase the concentrations of $\mathrm{Na}^{+}$and $\mathrm{HCO}_{3}$ in the groundwater.

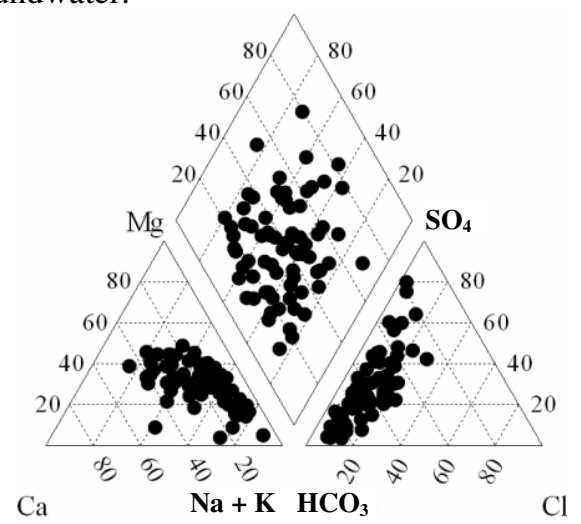

Figure 2. Piper diagram of groundwater

Groundwater in Pengyang County was comprehensively assessed with improved TOPSIS method described above. The weights determined by information entropy are listed in Table 3 and the quality assessment results are listed in Table 4.

Table 3. Information entropy and entropy weight of parameters

\begin{tabular}{cccccccc}
\hline Item & $\mathrm{Tfe}$ & $\mathrm{Cl}^{-}$ & $\mathrm{SO}_{4}{ }^{2-}$ & $\mathrm{NO}_{3}^{-}$ & $\mathrm{NO}_{2}^{-}$ & $\mathrm{NH}_{4}{ }^{+}$ & $\mathrm{F}^{-}$ \\
\hline$e_{j}$ & 0.967 & 0.994 & 0.994 & 0.990 & 0.990 & 0.997 & 0.983 \\
$\omega_{j}$ & 0.183 & 0.034 & 0.035 & 0.056 & 0.058 & 0.018 & 0.097 \\
item & $\mathrm{COD}$ & $\mathrm{TDS}$ & $\mathrm{TH}$ & $\mathrm{pH}$ & $\mathrm{As}$ & $\mathrm{I}$ & $\mathrm{Al}^{3+}$ \\
$e_{j}$ & 0.993 & 0.990 & 0.993 & 0.974 & 0.987 & 0.983 & 0.987 \\
$\omega_{j}$ & 0.041 & 0.055 & 0.041 & 0.143 & 0.073 & 0.097 & 0.070 \\
\hline
\end{tabular}


Table 4. Groundwater quality assessment results based on entropy weighted TOPSIS method

\begin{tabular}{|c|c|c|c|c|c|c|c|}
\hline No. & $C C$ & Rank & Description & No. & $C C$ & Rank & Description \\
\hline P01 & 0.962 & I & Excellent quality water & P14 & 0.912 & II & Good quality water \\
\hline P18 & 0.962 & I & Excellent quality water & $\mathrm{P} 02$ & 0.912 & II & Good quality water \\
\hline P20 & 0.961 & I & Excellent quality water & P51 & 0.910 & II & Good quality water \\
\hline P63 & 0.960 & I & Excellent quality water & P75 & 0.910 & II & Good quality water \\
\hline P56 & 0.959 & I & Excellent quality water & P68 & 0.907 & II & Good quality water \\
\hline P95 & 0.955 & I & Excellent quality water & P41 & 0.904 & II & Good quality water \\
\hline P64 & 0.951 & I & Excellent quality water & P09 & 0.904 & II & Good quality water \\
\hline $\mathrm{P} 21$ & 0.945 & I & Excellent quality water & P31 & 0.903 & II & Good quality water \\
\hline P16 & 0.945 & I & Excellent quality water & $\mathrm{P} 12$ & 0.902 & II & Good quality water \\
\hline P03 & 0.943 & I & Excellent quality water & P76 & 0.902 & II & Good quality water \\
\hline P88 & 0.941 & I & Excellent quality water & P89 & 0.900 & II & Good quality water \\
\hline P13 & 0.940 & I & Excellent quality water & P59 & 0.900 & II & Good quality water \\
\hline P77 & 0.939 & I & Excellent quality water & P39 & 0.900 & II & Good quality water \\
\hline P93 & 0.939 & I & Excellent quality water & P19 & 0.894 & II & Good quality water \\
\hline P66 & 0.938 & I & Excellent quality water & $\mathrm{P} 43$ & 0.893 & II & Good quality water \\
\hline P40 & 0.937 & I & Excellent quality water & P91 & 0.885 & II & Good quality water \\
\hline P37 & 0.936 & I & Excellent quality water & P83 & 0.877 & II & Good quality water \\
\hline P04 & 0.936 & I & Excellent quality water & P81 & 0.876 & II & Good quality water \\
\hline P61 & 0.930 & II & Good quality water & P62 & 0.876 & II & Good quality water \\
\hline P97 & 0.930 & II & Good quality water & P90 & 0.874 & III & Drinkable quality water \\
\hline P05 & 0.930 & II & Good quality water & P11 & 0.871 & III & Drinkable quality water \\
\hline P49 & 0.928 & II & Good quality water & P69 & 0.868 & III & Drinkable quality water \\
\hline P34 & 0.926 & II & Good quality water & P70 & 0.865 & III & Drinkable quality water \\
\hline P58 & 0.926 & II & Good quality water & P36 & 0.861 & III & Drinkable quality water \\
\hline P55 & 0.926 & II & Good quality water & P24 & 0.861 & III & Drinkable quality water \\
\hline P85 & 0.925 & II & Good quality water & P32 & 0.856 & III & Drinkable quality water \\
\hline P45 & 0.925 & II & Good quality water & P60 & 0.855 & III & Drinkable quality water \\
\hline P92 & 0.924 & II & Good quality water & $\mathrm{P} 22$ & 0.854 & III & Drinkable quality water \\
\hline P35 & 0.923 & II & Good quality water & P74 & 0.852 & III & Drinkable quality water \\
\hline P79 & 0.919 & II & Good quality water & P86 & 0.851 & III & Drinkable quality water \\
\hline P79 & 0.919 & II & Good quality water & P87 & 0.843 & III & Drinkable quality water \\
\hline P07 & 0.918 & II & Good quality water & P27 & 0.839 & III & Drinkable quality water \\
\hline P46 & 0.917 & II & Good quality water & P50 & 0.830 & III & Drinkable quality water \\
\hline P53 & 0.917 & II & Good quality water & P71 & 0.825 & III & Drinkable quality water \\
\hline P33 & 0.917 & II & Good quality water & P72 & 0.817 & III & Drinkable quality water \\
\hline P52 & 0.916 & II & Good quality water & P73 & 0.798 & III & Drinkable quality water \\
\hline $\mathrm{P} 10$ & 0.915 & II & Good quality water & $\mathrm{P} 38$ & 0.788 & III & Drinkable quality water \\
\hline
\end{tabular}

It can be seen from the assessment results that the groundwater quality in the study area is relatively good and is fit for human consumption. Of the 74 groundwater samples, 18 samples are excellent quality water, 38 samples are good quality water and 18 samples belong to drinkable quality water, accounting for $24.32 \%, 51.36 \%$ and $24.32 \%$ of the total samples respectively. The quality of groundwater has been found to be closely related with the high values of TDS, fluoride, sulphate, nitrite and TH according to the entropy weights. 


\section{Inverse geochemical modeling}

The inverse geochemical modeling was performed with PHREEQC hydrogeochemical modeling software. The inverse geochemical modeling requires that water sampling points be in the same water flow path ${ }^{4}$. Hence, the 3 paths selected in this study are all along the groundwater flow path (Figure 1). According to the measurement and analysis of aquifer minerals, groundwater chemical compositions and conditions of groundwater occurrence, halite, sodium montmorillonite, calcite, dolomite, gypsum, halite, fluorite, albite, $K$-feldspar and $\mathrm{CO}_{2}$ are selected as the possible mineral phases. The role of cation exchange in the groundwater is of great significance in the evolution of hydrochemical composition, so cation exchange is selected as a possible mineral phase in the groundwater too. The simulated results of the 3 paths are listed in Table 5.

Table 5. Calculation results of amount of minerals dissolved or precipitated

\begin{tabular}{lccccccccccc}
\hline \multirow{2}{*}{ Path } & \multicolumn{8}{c}{ Amount of minerals dissolved or precipitated, mmol/L } \\
\cline { 2 - 12 } & Gypsum & $\begin{array}{c}\text { Sodium } \\
\text { montmorillonite }\end{array}$ & Fluorite Calcite Halite Dolomite & $\mathrm{CO}_{2}$ & Albite K-feldspar & $\mathrm{NaX}$ & $\mathrm{CaX}_{2}$ \\
\hline Path 1 & 1.0 & -5.0 & 0.02 & -3.2 & 4.5 & 0.2 & 1.6 & 6.1 & 0.00 & -4.4 & 2.2 \\
Path 2 & 2.8 & -7.5 & 0.07 & -4.1 & 2.9 & 1.0 & 5.1 & 9.1 & 0.06 & 0.4 & -0.2 \\
Path 3 & -7.6 & -6.0 & -0.06 & 4.7 & 0.0 & -0.1 & -8.7 & 7.3 & 0.03 & -5.0 & 2.5 \\
\hline
\end{tabular}

Note: positive for dissolution, negative for precipitation

It can be seen from the simulation results that during the groundwater flow on path 1, the precipitation of sodium montmorillonite, calcite occurred. At the same time, gypsum, fluorite, halite, albite and dolomite dissolved into groundwater with different amounts. Cation exchange and $\mathrm{CO}_{2}$ emission occurred as well. During the cation exchange, $\mathrm{Na}^{+}$from the halite and albite dissolved into the water and then exchanged with $\mathrm{Ca}^{2+}$ and was absorbed into the rock or clay surface. The largest precipitation is caused by sodium montmorillonite, up to $5.0 \mathrm{mmol} / \mathrm{L}$ and the largest dissolution is albite, reaching $6.1 \mathrm{mmol} / \mathrm{L}$. It can be seen from the results that the cation exchange plays a significant role in controlling the groundwater chemistry. Along the flow path, the concentrations of $\mathrm{Na}^{+}, \mathrm{Cl}^{-}, \mathrm{Mg}^{2+}, \mathrm{SO}_{4}{ }^{2-}$ and $\mathrm{F}^{-}$gradually increased, which could be attributed to the dissolution of halite, albite, dolomite, gypsum and fluorite, respectively. All these reactions occurred during the water flow resulted in the water chemistry variation from $\mathrm{HCO}_{3} \cdot \mathrm{SO}_{4}-\mathrm{Na} \cdot \mathrm{Mg}$ type to $\mathrm{SO}_{4} \cdot \mathrm{Cl} \cdot \mathrm{HCO}_{3}-\mathrm{Na}$ type. The albite dissolution did not cause the $\mathrm{Al}(\mathrm{OH})_{4}{ }^{-}$and $\mathrm{SiO}_{2}$ concentrations to increase as we have expected. However, taking into account a large amount of precipitation of sodium montmorillonite, we have sufficient reason to believe that $\mathrm{Al}(\mathrm{OH})_{4}{ }^{-}$and $\mathrm{SiO}_{2}$, along with the relevant ions in the aqueous solution, have formed the sodium montmorillonite, that is to say, the dissolution of albite has led to the precipitation of sodium montmorillonite, which is a common albite weathering result in nature ${ }^{6}$. The dissolved $\mathrm{CO}_{2}$ caused the $\mathrm{pH}$ value to decrease, promoting the dissolution of gypsum.

On simulated path 2, similar reactions to that on path 1 occurred during the groundwater flow through the aquifer media. However, what make the differences between the two paths are the amounts of the mineral dissolution and precipitation as well as the cation exchange pattern. On path 2, all the minerals except halite showed larger amounts of dissolution and precipitation than that on path 1 . The largest precipitation and dissolution amounts caused by sodium montmorillonite and albite are 7.5 and $9.1 \mathrm{mmol} / \mathrm{L}$, respectively. Further more, the cation exchange pattern on path 2 is different from that on path 1 . On path 2 , the $\mathrm{Na}^{+}$absorbed 
on the rock surface was exchanged with $\mathrm{Ca}^{2+}$ and dissolved into the water. Reactions occurred on path 3 are a little different from that occurred on path 1 or path 2 . On path 3 , gypsum and sodium montmorillonite precipitation play the leading role in precipitation reactions with precipitation amounts of 7.6 and $6.0 \mathrm{mmol} / \mathrm{L}$, respectively and albite is still significantly influencing the dissolution reactions with dissolution amount of $7.3 \mathrm{mmol} / \mathrm{L}$. It can be seen from the comparison of the three paths that gypsum, fluorite, dolomite and $\mathrm{CO}_{2}$ all dissolved into the groundwater and calcite precipitated from the groundwater on path 1 and path 2, while on path 3, these reactions are opposite. Gypsum, fluorite, dolomite and $\mathrm{CO}_{2}$ all precipitated from the water and calcite dissolved into the groundwater. It is a key point in this study to explain this phenomenon precisely and clearly. In the specific environment, the initial solution of path 3 is oversaturated with $\mathrm{CaSO}_{4}$ and $\mathrm{CaMg}\left(\mathrm{CO}_{3}\right)_{2}$. When the solution is oversaturated with $\mathrm{CaSO}_{4}$ and $\mathrm{CaMg}\left(\mathrm{CO}_{3}\right)_{2}, \mathrm{CaSO}_{4}$ and $\mathrm{CaMg}\left(\mathrm{CO}_{3}\right)_{2}$ will precipitate from the solution. With the precipitation of $\mathrm{CaSO}_{4}$ and $\mathrm{CaMg}\left(\mathrm{CO}_{3}\right)_{2}$ and groundwater flow, the $\mathrm{Ca}^{2+}$ becomes less and less, which causes the solution to be unsaturated with $\mathrm{CaCO}_{3}$, causing the $\mathrm{Ca}^{2+}$ containing minerals to be dissolved into the water. Actually, these reactions usually occur in different sections of the flow path, respectively. The decrease of $\mathrm{F}^{-}$can attributed to the precipitation of fluorite accordingly. The precipitation of gypsum makes the $\mathrm{SO}_{4}{ }^{2-}$ concentration decrease and $\mathrm{CO}_{2}$ emission may lead to the $\mathrm{pH}$ rising. It can be concluded from the phenomenon that chemical reactions occurred in the groundwater are complex and are greatly influenced by the initial aquatic environment and hydrodynamic conditions of the flow path.

\section{Conclusion}

Based on the collection and chemical analysis of groundwater samples, entropy weighted TOPSIS method is used to perform groundwater quality assessment in this study and inverse geochemical modeling is used in this paper to quantitatively study the formation mechanisms of groundwater. The following conclusions are summarized:

(1) Groundwater quality assessment results show that the groundwater in Pengyang County is generally fit for human consumptions and the high concentrations of some elements or irons are attributed to the strong water-rock interactions which are highly depended on the hydrogeological conditions and hydrodynamic conditions along the groundwater flow path.

(2) The inverse geochemical modeling reveals that the precipitation of sodium montmorillonite, calcite and the dissolutions of gypsum, fluorite, halite, albite and dolomite are the major water-rock interactions occurred in the south part of the study area, $\mathrm{CO}_{2}$ dissolution and cation exchange also play important roles in the determination of hydrochemistry. While in the north part, the leading reactions are the precipitation of gypsum, dolomite, sodium montmorillonite, fluorite, the dissolution of calcite and albite and the $\mathrm{CO}_{2}$ emission and cation exchange are also important. All these reactions are influenced by the initial aquatic environment and hydrodynamic conditions of the flow path.

\section{Acknowledgment}

This work was supported by the National Natural Science Foundation of China (Grant No. 40772160), the Research on Drinking Water Environment and Endemic in Villages and Small Towns in New Socialist Countryside Project (Grant No. 010) supported by the Ningxia Land and Resources Department. 


\section{References}

1. Qiu J, Nature, 2010, 466, 308.

2. Wang G C, Tao S, Shen Z L and Zhong Z X, Science in China (Series D), 1998, 41(4), 377-381.

3. Gillon M, Crançon P and Aupiais J, Appl Geochem., 2010, 25(10), 1564-1574.

4. $\quad$ Li P Y, Qian H, Wu J H and Ding J, Water Sci Eng., 2010, 3(3), 282-291.

5. Sharif M U, Davis R K, Steele K F, Kim B, Kresse T M, and Fazio J A, J Hydrology, 2008, 350(1-2), 41-55.

6. Abu-Jaber N and Ismail M, Environmental Geology, 2003, 44(4), 391-399.

7. Hwang C L and Yoon K, Multiple Attribute Decision Making Methods and Applications, Springer-Heidelberg, Berlin, 1981.

8. Jahanshahloo G R, Hosseinzadeh Lotfi F and Izadikhah M, Applied Mathematics and Computation, 2006, 175, 1375-1384.

9. Sadi-Nezhad S and Damghani K K, Applied Soft Computing, 2010, 10, 1028-1039.

10. Kelemenis A and Askounis D, Expert Systems with Applications, 2010, 37(7), 4999-5008.

11. Afshar A, Mariño M A, Saadatpour M and Afshar A, Water Resour Manage., 1011, 25, 545-563.

12. $\quad$ Ding S F and Shi Z Z, J Information Sci., 2005, 31(6), 497-502.

13. Li P Y, Wu J H and Qian H, Int J Environ Sci., 2010, 1(4), 621-630.

14. Chen S Z, Wang X J and Zhao X J, J China University of Mining and Technol., 2008, 18(1), 72-75.

15. Liu R T, Fu Q and Gai Z M, J Northeast Agricultural University, 2007, 14(4), 368-373.

16. Men B H, Fu Q and Zhao X M, J Northeast Agricultural University, 2004, 11(1), 66-68. 


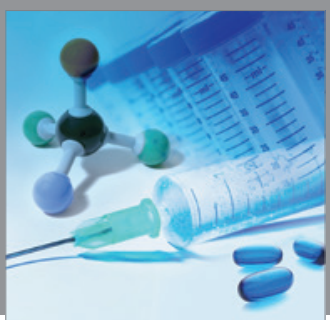

International Journal of

Medicinal Chemistry

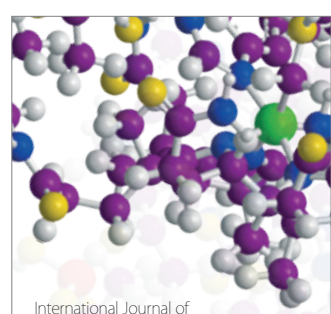

Carbohydrate Chemistry

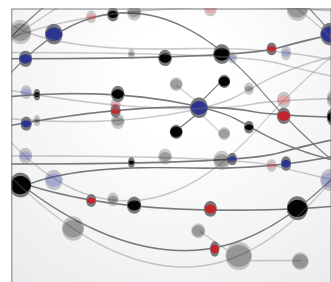

The Scientific World Journal
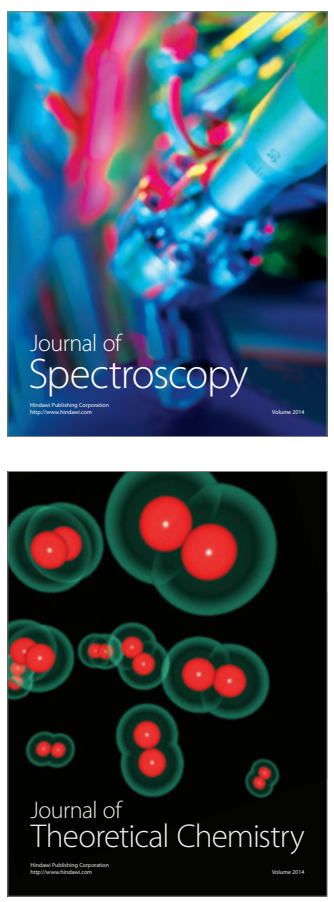
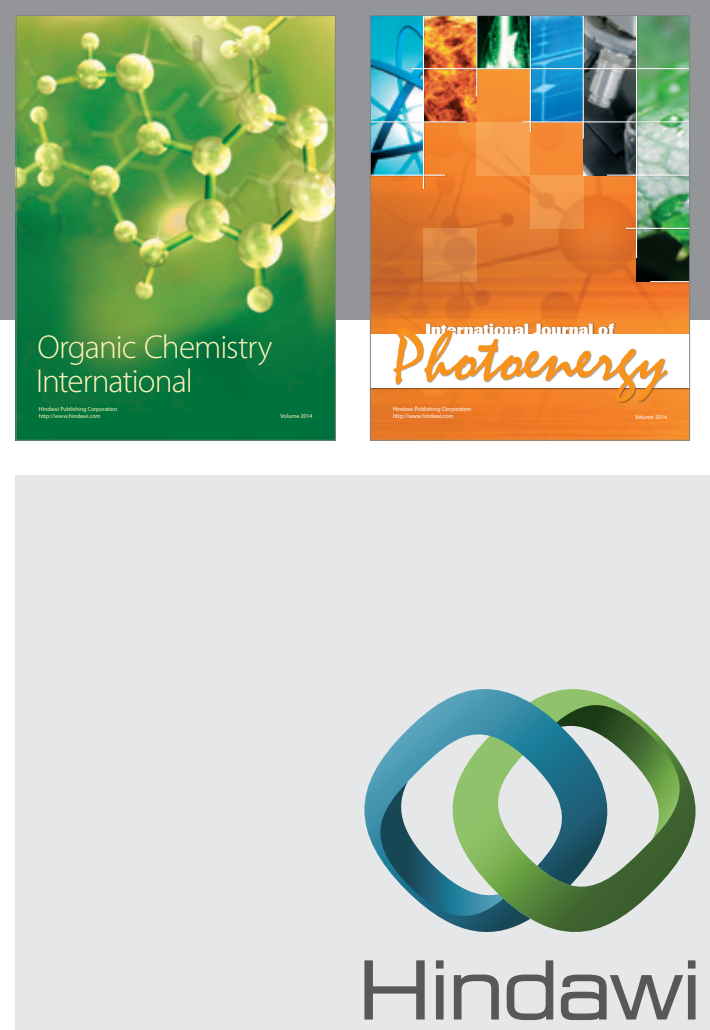

Submit your manuscripts at

http://www.hindawi.com
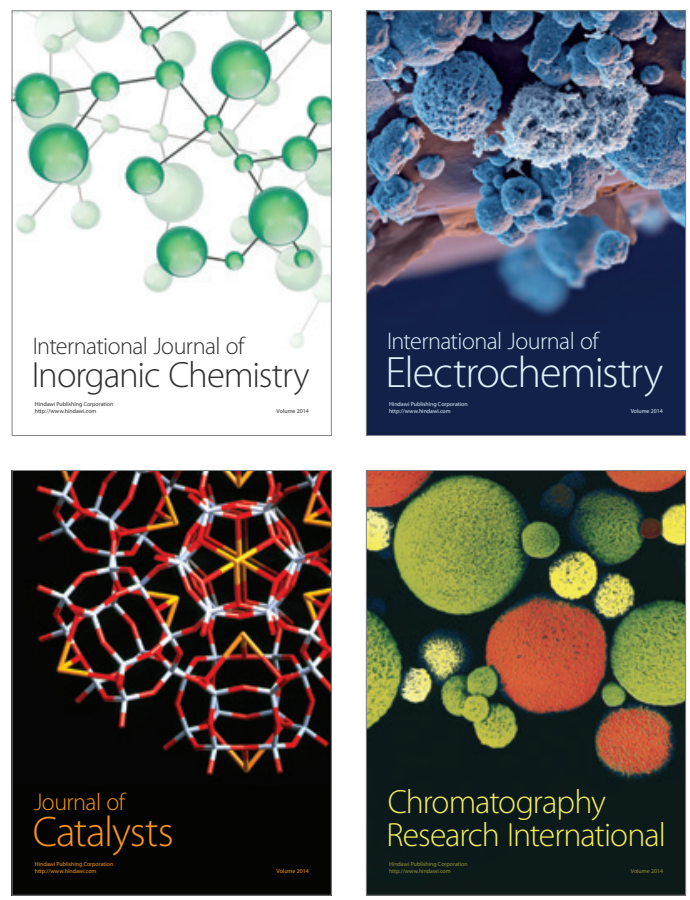
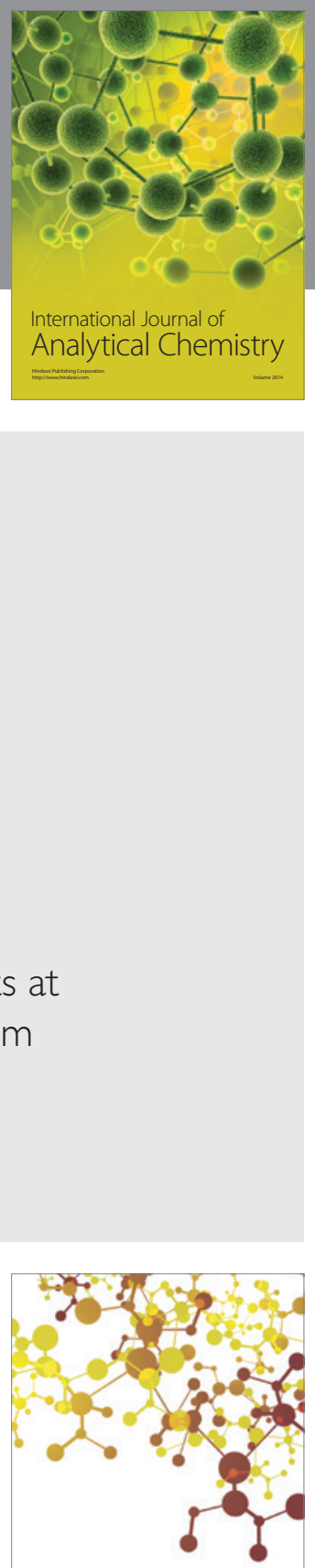

Journal of

Applied Chemistry
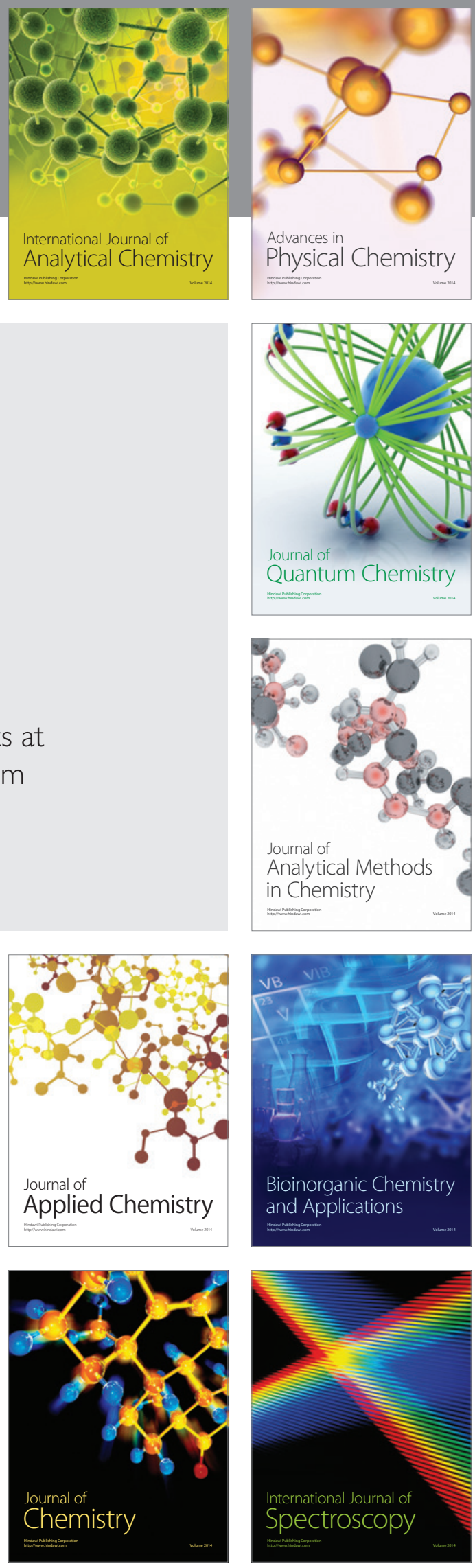